\title{
Knowledge of Helminthiasis of People Living in Slum Areas of Bandung District, Indonesia
}

\author{
Lia Faridah, ${ }^{1}$ Nisa Fauziah,, ${ }^{1}$ Riyadi Adrizain ${ }^{2}$ \\ ${ }^{1}$ Division of Parasitology, Department of Biomedical Science Faculty of Medicine \\ Universitas Padjadjaran, Bandung, Indonesia, ${ }^{2}$ Department of Child Health Faculty of Medicine \\ Universitas Padjajaran/Dr. Hasan Sadikin General Hospital Bandung, Indonesia
}

\begin{abstract}
Among the most prevalent infections worldwide, Soil-Transmitted Helminth (STH) infection is the one that affects the poorest and most deprived populations. Data from the WHO shows that more than 1.5 billion people are affected by soil-transmitted helminth diseases globally. In 2010, it was estimated that 819.0 million, 464.6 million, and 438.9 million people around the world were infected with Ascaris lumbricoides, Trichuris trichiura, and hookworms (Ancylostoma duodenale and Necator americanus), respectively, with the Southeast Asia as the region with the highest prevalence of STH. Children's awareness and knowledge of helminthiasis are essential to reduce the STH infection prevalence. Unfortunately, evaluation on children's understanding of helminthiasis is still scarce. This study was intended to measure children's knowledge of STH infections and its prevention, especially prevention measures at home, in Bandung District, Indonesia. This study was conducted in March 2021 on 506 children who lived in 15 different subdistricts in Bandung District. Data were collected through a questionnaire that was used for face-to-face interviews with the children. All data were recorded in RedCap apps for further analysis. It was demonstrated in this study that children in Bandung District generally have lowto-medium knowledge on helminthiasis prevention, symptoms, and treatment (85\%). Thus, there is an urgent need for an education program on helminthiasis to complement the deworming measures conducted by the local government.
\end{abstract}

Keywords: Helminthiasis, knowledge, population

\section{Pengetahuan tentang Helminthiasis pada Penduduk yang Tinggal di Kawasan Kumuh Kabupaten Bandung, Indonesia}

\begin{abstract}
Abstrak
Di antara infeksi yang paling umum terjadi di seluruh dunia, yaitu infeksi cacing yang ditularkan melalui tanah, soil transmitted helmint (STH) adalah infeksi yang menyerang penduduk termiskin dan paling tertinggal. Data dari WHO secara global menunjukkan bahwa lebih dari 1,5 miliar masyarakat terkontaminasi oleh penyakit cacing yang ditularkan melalui tanah. Pada tahun 2010, diperkirakan 819,0 juta, 464,6 juta dan 438,9 juta jiwa di seluruh dunia terinfeksi masing-masing oleh Ascaris lumbricoides, Trichuris trichiura, dan cacing tambang (Ancylostoma duodenale dan Necator americanus), Asia Tenggara sebagai wilayah dengan pravalensi STH tertinggi. Kesadaran dan pengetahuan anak mengenai infeksi akibat cacing masih langka. Penelitian ini bertujuan mengukur pengetahuan anak mengenai STH dan pencegahannya, khususnya tindakan pencegahan di rumah, di Kabupaten Bandung, Indonesia. Penelitian ini dilakukan pada bulan Maret 2021 melalui kuesioner yang disebarkan kepada 506 anak yang tinggal di kecamatan berbeda di Kabupaten Bandung untuk mengumpulkan data. Data diperoleh melalui wawancara dengan anak-anak tersebut berdasar atas kuesioner yang diberikan. Semua data disimpan dalam aplikasi RedCap untuk selanjutnya dilakukan analisis. Pada penelitian ini terlihat bahwa anak-anak di Kabupaten Bandung pada umumnya memiliki pengetahuan rendah sampai menengah tentang pencegahan, gejala, dan pengobatan infeksi akibat cacing (85\%). Perlu program edukasi mengenai cacing untuk melengkapi upaya pemberantasan cacing yang dilakukan oleh pemerintahan daerah.
\end{abstract}

Kata kunci: Infeksi cacing, pengetahuan, populasi

Corresponding author: Lia Faridah, Division of Parasitology, Department of Biomedical Science Faculty of Medicine Universitas Padjadjaran, Indonesia, Email: lia.faridah@unpad.ac.id 


\section{Introduction}

Among the most prevalent infections worldwide, soil-transmitted helminth (STH) infection is the one that affects the poorest and most deprived populations. The risk factors for STH infection are closely related to clean and healthy living behavior. ${ }^{1}$ Helminth eggs are found in human feces, which may, in turn, contaminate the soil in areas where sanitation is poor. The ground then becomes the medium for disease transmission. Data from the World Health Organization (WHO) shows that more than 1.5 billion people worldwide are contaminated by soil-transmitted helminth diseases. Infections occur extensively in tropical and subtropical countries, subSaharan Africa, the Americas, China, and East Asia contribute the highest number. ${ }^{2}$

There are 4 species of STH that infect human, i.e. Ancylostoma duodenale, Necator americanus, Ascaris lumbricoides, and Trichuris trichiura. ${ }^{2}$ In 2010, 819.0 million people were infected with A. lumbricoides, while 464.6 million and 438.9 million people were estimated to be infected with T. trichiura and hookworms (A. duodenale and $N$. americanus), respectively. The Southeast Asian region has been the region with the highest prevalence of STH in recent decades. ${ }^{4}$ Among the 11 countries of Southeast Asia, In this region, Indonesia has been identified as the country with the most significant number of ascariasis and trichuriasis cases and hookworm cases. ${ }^{5-7}$

More than 613 million school-age children were reported to be at risk of this infection globally in 2010, ${ }^{8,9}$ Malnourishment, poor academic performance, delayed physical development, and cognitive impairment are some of the effects of these parasites in children. ${ }^{10-12}$

Mitigation efforts to reduce the prevalence of STH in Indonesia have been made by the Ministry of Health $(\mathrm{MoH})$ Indonesia. The $\mathrm{MoH}$ regulation No. 15 of 2017 includes the WHO-recommended deworming program to be implemented in areas with a high STH prevalence, advising annual treatment for areas with 20-50\% prevalence and biannual treatment for sites with a majority that is higher than $50 \%{ }^{13}$ Besides STH infection, it is also important to note that several other etiological factors, including the quality and quantity of nutrient intake as well as environmental enteropathy, may also contribute to malnutrition and anemia. ${ }^{14-16}$ Before the implementing of the program, a survey is needed (1) to evaluate children's knowledge regarding STHs symptoms, transmission, and their prevention measures, and (2) to evaluate children's personal hygiene practices to STH. This research is aimed to provide a baseline for the project and plan relevant school-based education activities for the STH control program, especially in Bandung Regency, Indonesia.

\section{Methods}

This was a cross-sectional survey in a community in 39 villages of 81 villages in Bandung District. The thirty-nine villages were selected using the multistage random sampling method with RAND running on excel used for the randomization process.

The sample size was calculated to determine the prevalence of helminthiasis in stunting children. A formula was used to estimate the population proportion using the following equation:

$$
\mathrm{n}=\mathrm{p}(1-\mathrm{p}) \frac{(\mathrm{Z} \alpha)^{2}}{\mathrm{~d}}
$$

Where $\mathrm{n}$ is sample size, $\mathrm{p}$ is estimated prevalence of helminthiasis, $\mathrm{Z} \alpha$ is standard deviation value as obtained from the standard typical distribution table for the selected confidence level, and $d$ is amount of precision.

In this study, the level of confidence of (1a) $99 \%(Z \alpha=2.575)$ was selected with the magnitude of $\mathrm{p}=0.20$ and amount of precision (d) of 0.05. Based on the sample size formula above, the minimum sample size of the survey's respondents was 425. (Number of samples taken in this research is 507).

A validated questionnaire consisting of 29 questions in 4 parts (socio-demographic characteristics, clinical manifestation, and knowledge regarding helminthiasis) was used to collect data in this study. This study was approved by the ethics committee of Universitas Padjajaran with the ethical clearance registration number 071711.

Three research assistants were standardized before collecting data. Data were collected through face-to-face interviews that lasted 10 minutes for completion. Permission for data collection activities was obtained from Bandung District Government and Bandung Regency Health Office under the Helminthiasis project. Informed consent was obtained from the mothers who come to the Bandung Regency Health Office. After an explanation was provided on the purpose of the study and asking the willingness of the respondents to share their 
information. All data were recorded in RedCap apps for further analysis.

Responses from the survey were documented into a binary array (1-0), and scoring was performed for the total number of 'yes' answers. The scores were then classified as low (below or equal to the first quartile), medium (between first and third quartile), and high (equal and above the third quartile). Each question in the survey were checked for its $95 \%$ confidence interval and margin of error.

\section{Results}

In this study, we collected 506 children across Bandung District, Indonesia. Of these, 51.8\% were identified as females and $48.2 \%$ as male (Table 1). The most significant portion of respondents $(65.41 \%)$ had a family income of IDR 500,000-2,000,000 per month, and only $1.38 \%$ of the respondents had a family income of more than IDR 5,000,000 per month. Only $2.17 \%$ and $1.78 \%$ of the fathers and the respondent's mothers had an undergraduate level of education. The fathers mostly worked as laborers $(62.45 \%)$, while most mothers were unemployed or a housewife $(80.03 \%)$. In terms of the ownership of insurance coverage, no significant difference was observed $(52.37 \%$ vs. $46.83 \%)$.

We include 14 binary yes-no questions in the questionnaire. However, no question was answered positively by more than $50 \%$ of the children (Table 2). The highest-scoring question was from the Symptoms category, i.e., 'Know more than one symptom of helminthiasis'. The

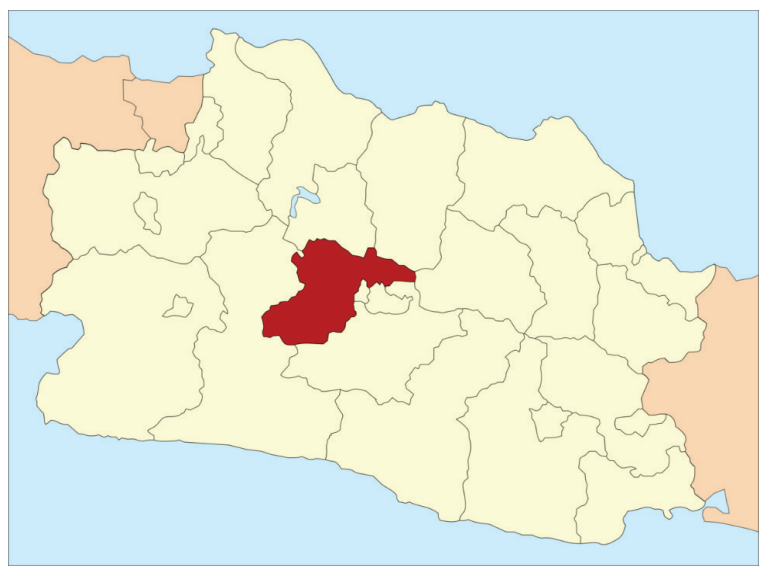

Figure 1 Regency as the Population of the Study, Located in the Heart of West Java, Indonesia
Table 1 Demographic Data of Children from Bandung District, West Java, Indonesia

\begin{tabular}{|c|c|}
\hline Characteristics & $\%(N=506)$ \\
\hline \multicolumn{2}{|l|}{ Sex } \\
\hline Male & $48.2(244)$ \\
\hline Female & $51.8(262)$ \\
\hline \multicolumn{2}{|l|}{ Age (years old) } \\
\hline 6 & $0.59(3)$ \\
\hline 5 & $30.63(155)$ \\
\hline 4 & 35.17 (178) \\
\hline 3 & $28.85(146)$ \\
\hline$<3$ & $4.15(21)$ \\
\hline \multicolumn{2}{|l|}{ Family income } \\
\hline Not answered & $1.58(8)$ \\
\hline $500,000-2,000,000$ & $65.41(331)$ \\
\hline $2,000,000-3,500,000$ & $24.9(126)$ \\
\hline $3,500,000-5,000,000$ & $6.32(32)$ \\
\hline$>5,000,000$ & $1.38(7)$ \\
\hline \multicolumn{2}{|l|}{ Father's education } \\
\hline Primary & $36.75(186)$ \\
\hline Secondary (Middle school) & $34.4(174)$ \\
\hline Tertiary (High school) & $26.48(134)$ \\
\hline Undergraduate & $2.17(11)$ \\
\hline $\begin{array}{l}\text { Not taking any formal } \\
\text { education }\end{array}$ & $0.2(1)$ \\
\hline \multicolumn{2}{|l|}{ Father's occupation } \\
\hline Unemployed & $1.38(7)$ \\
\hline Government employee & $1.19(6)$ \\
\hline Non-government employee & $10.28(52)$ \\
\hline Entrepreneur & $13.44(68)$ \\
\hline Labor & $62.45(316)$ \\
\hline Farmer & $3.16(16)$ \\
\hline Others & $8.1(41)$ \\
\hline \multicolumn{2}{|l|}{ Mother's education } \\
\hline Primary & $34.78(176)$ \\
\hline Secondary (middle school) & $36.56(185)$ \\
\hline Tertiary (high school) & $25.89(131)$ \\
\hline Undergraduate & $1.78(9)$ \\
\hline $\begin{array}{l}\text { Not taking any formal } \\
\text { education }\end{array}$ & $0.79(4)$ \\
\hline \multicolumn{2}{|l|}{ Mother's occupation } \\
\hline Unemployed (housewife) & $80.03(405)$ \\
\hline
\end{tabular}


Tabel 1 (continued)

\begin{tabular}{lc}
\hline \multicolumn{1}{c}{ Characteristics } & \% (N=506) \\
\hline Non-government employee & $2.17(11)$ \\
Entrepreneur & $2.57(13)$ \\
Labor & $8.1(41)$ \\
Farmer & $1.19(6)$ \\
Others & $5.73(29)$ \\
Health insurance & \\
Insured & $52.37(265)$ \\
Not insured & $46.83(237)$ \\
\hline
\end{tabular}

question was answered positively by about $32.8 \%$ of the respondents. Nevertheless, three questions received low scores: 'Know how to prevent disease by using footwear,' 'Know how to prevent disease by using proper toilet,' and 'Know how to prevent disease by drinking clean water.'

The resulting scores were then categorized into three categories: high, medium, and low (Figure 1). Figure 1 shows that low-scoring respondents contributed to the most significant portion and that the overall score was common for all respondents.

Drugs for preventing disease were the most recognizable knowledge among the respondents.

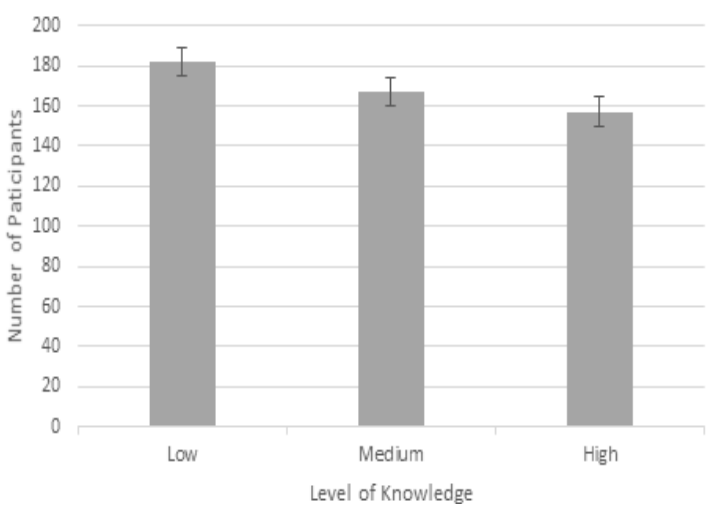

Figure 2 Distribution of Knowledge Level among Respondents

Ability of symptoms was demonstrated by symptoms consisting of diarrhea, fatigue, pale, anemia, skinniness, appetite, and laziness. The above table only presents two of the symptoms of helminthiasis. Fatigue was the most common symptom known by the respondents. Although helminthiasis could be transmitted through food and foot/hand., the ratio of respondents who know that food and foot/hand could transmit the disease was only $7.11 \%$.

No discernible difference was observed in the knowledge regarding the prevention, symptoms, and transmission among survey respondents

Table 2 Respondents' Knowledge of Helminthiasis Symptoms, Transmission, and Prevention

\begin{tabular}{lcc}
\hline \multicolumn{1}{c}{ Indicators } & (n=506) & (\%) (97.5\% CI) \\
\hline Prevention of disease & & \\
Know how to prevent disease by washing hands before eating & 62 & $12.25(9.39-15.11)$ \\
Learn how to avoid illness by washing hands after defecating & 45 & $8.89(6.41-11.37)$ \\
Learn how to avoid illness by wearing footwear & 6 & $1.18(0.24-2.12)$ \\
Know how to prevent disease by using a proper toilet & 7 & $1.38(0.36-2.4)$ \\
Learn how to prevent illness by maintaining food/beverage hygiene & 63 & $12.45(9.57-15.3)$ \\
Learn how to avoid illness by clipping nails routinely & 10 & $1.97(0.76-3.18)$ \\
Learn how to avoid illness by drinking clean water & 1 & $0.19(-0.18-0.58)$ \\
Learn how to avoid illness by consuming drugs & 292 & $57.7(53.4-62.01)$ \\
Symptoms & & 13 \\
Know one of the signs of helminthiasis is diarrhea & 166 & $32.8(28.71-36.89)$ \\
Know more than one symptom of helminthiasis & 157 & $31.03(26.9-35.05)$ \\
Know helminthiasis could cause fatigue & & 128 \\
Transmission & 124 & $25.29(21.51-29.08)$ \\
Know that food can transmit a parasite & 36 & $7.11(4.87-9.35)$ \\
Know that foot/hand can transmit a parasite &
\end{tabular}


(Figure 2). Most of the respondents were in the category of low level of knowledge, which represented a score of less or equal to the $1^{\text {st }}$ quartile.

\section{Discussion}

This study was carried out to evaluate children's knowledge regarding helminthiasis prevention, symptoms, and treatment. Children's understanding of helminthiasis is essential to reduce the transmission of the disease. There has been a considerable amount of studies regarding neglected tropical diseases knowledge in various regions of the world, many of which indicate that the level of the command is still dissatisfying. ${ }^{17,18}$ Moreover, studies on this aspect in the Bandung area are still limited. This study has demonstrated that most children participating in this study have a low to medium levels knowledge of helminthiasis prevention, symptoms, and treatment. Findings in this study could be further explored with those of similar studies that have been conducted in Sumatra and Sumba ${ }^{19}$, in which the relation between the habits and the infection risk can be assessed.

'Prevention of the disease' section of the questionnaire is observed to be low scoring among other areas. The low score could indicate the lack of health education from the local doctor or authorities. However, the respondents in this study are the high-risk age group which also can transmit the disease due to their high-risk behavior. ${ }^{20}$ It appears that the crucial information regarding the prevention of the disease is failing to reach this target age group. Besides regular primary health care-targeting program, another approach to educating school teachers and parents could be beneficial to the impact of the deworming program.

It is demonstrated in our study that children do does not understand the importance of clean water, noting that only one respondent understands the crucial role of clean water in preventing the disease. Yet, to effectively implement the deworming program, measures should also be implemented to eliminate poor sanitation habits as it can be one of the factors that hinder the success of eradication. ${ }^{19}$ Hence, it is necessary to complement the deworming policy with an education program to improve sanitation habits. This calls the need to educate children on the importance of drinking clean water.

In conclusion, study respondents in Bandung generally have low-to-medium knowledge regarding helminthiasis prevention, symptoms, and treatment, accounting for around $85 \%$ of all respondents. Therefore, there is an urgent need to implement an education program to complement the deworming initiatives conducted by the local government.

\section{References}

1. Vaz Nery S, Pickering AJ, Abate E, Asmare A, Barrett L, Benjamin-Chung J, et al. The role of water, sanitation and hygiene interventions in reducing soil-transmitted helminths: interpreting the evidence and identifying next steps. Parasites Vectors. 2019;12(1):1-8.

2. WHO. Soil-transmitted helminths infections. US: World Health Organization. 2017.

3. Pullan RL, Gething PW, Smith JL, Mwandawiro CS, Sturrock HJW, Gitonga CW, et al. Spatial modeling of soil-transmitted helminth infections in Kenya: A disease control planning tool. PLoS Negl Trop Dis. 2011;5(2):e958.

4. Pullan RL, Smith JL, Jasrasaria R, Brooker SJ. Global numbers of infection and disease burden of soil-transmitted helminth infections in 2010. Parasit Vectors. 2014;7:37.

5. Lee J, Ryu JS. Current status of parasite infections in Indonesia: a literature review. Korean J Parasitol. 2019;57(4):329-39.

6. Pullan RL, Smith JL, Jasrasaria R, Brooker SJ. Global numbers of infection and disease burden of soil-transmitted helminth infections in 2010. Parasit Vectors. 2014;7:37.

7. Kattula D, Sarkar R, Rao Ajjampur SS, Minz S, Levecke B, Muliyil J, et al. Prevalence \& risk factors for soil transmitted helminth infection among school children in south India. Indian J Med Res. 2014;139(1):76-82.

8. WHO. Soil-transmitted helminthiases: number of children treated in 2010. Wkly Epidemiol Rec. 2012;87(23):225-32.

9. Novianty S, Dimyati Y, Pasaribu S, Pasaribu AP. Risk factors for soil-transmitted helminthiasis in preschool children living in Farmland, North Sumatera, Indonesia. J Trop Med. 2018;2018:6706413.

10. Ahmed A, Al-Mekhlafi HM, Azam MN, Ithoi I, Al-Adhroey AH, Abdulsalam AM, et al. Soil-transmitted helminthiasis: a critical but neglected factor influencing school 
participation of Aboriginal children in rural Malaysia. Parasitology. 2012;139(6):802-8

11. Isah AUJ, Ekwunife OI, Ejie IL, Mandrik O. Effects of nutritional supplements on the reinfection rate of soil-transmitted helminths in school-age children: A systematic review and meta-analysis. PLoS One. 2020;15(8):e0237112.

12. Shrestha A, Schindler C, Odermatt P, Gerold J, Erismann S, Sharma S, etal. Intestinal parasite infections and associated risk factors among schoolchildren in Dolakha and Ramechhap districts, Nepal: a cross-sectional study. Parasit Vectors. 2018;11(1):532.

13. World Health Organization. Soil-transmitted helminthiases: number of children (pre-SAC and SAC) requiring preventive chemotherapy for soil-transmitted helminthiases: 2019. Geneva: World Health Organization; 2020.

14. Ansuya, Nayak BS, Unnikrishnan B, George A, N SY, Mundkur SC, et al. Risk factors for malnutrition among preschool children in rural Karnataka: a case-control study. BMC Public Health. 2018;18:283.

15. Kang Y, Aguayo VM, Campbell RK, Dzed L, Joshi V, Waid JL, et al. Nutritional status and risk factors for stunting in preschool children in Bhutan. Matern Child Nutr. 2018;(14 Suppl 4):e12653.

16. Ahmed A, Al-Mekhlafi HM, Al-Adhroey
AH, Ithoi I, Abdulsalam AM, Surin J. The nutritional impacts of soil-transmitted helminths infections among Orang Asli schoolchildren in rural Malaysia. Parasit Vectors. 2012;5:119.

17. Pasaribu AP, Alam A, Sembiring K, Pasaribu S, Setiabudi D. Prevalence and risk factors of soil-transmitted helminthiasis among school children living in an agricultural area of North Sumatera, Indonesia. BMC Public Health. 2019;19(1):1066.

18. Musuva RM, Awiti A, Omedo M, Ogutu M, Secor WE, Montgomery SP, et al. Community knowledge, attitudes and practices on schistosomiasis in western Kenya-the SCORE Project. Am J Trop Med Hyg. 2014;90(4):646-52.

19. Saha A, Sarker M, Kabir M, Lu G, Müller 0 . Knowledge, attitudes, and practices regarding malaria control among the slash and burn cultivators in Rangamati Hill tracts of Bangladesh. Malar J. 2019;18(1):216.

20. Midzi N, Mtapuri-Zinyowera S, Mapingure MP, Paul NH, Sangweme D, Hlerema G, et al. Knowledge attitudes and practices of grade three primary schoolchildren in relation to schistosomiasis, soil transmitted helminthiasis and malaria in Zimbabwe. BMC Infect Dis. 2011;11:169. 